Portland State University

PDXScholar

$5-24-2019$

\title{
The Ripples of Vanport: Navigating Competing Narratives
}

Curtis J. Jewell

Portland State University

Follow this and additional works at: https://pdxscholar.library.pdx.edu/honorstheses

\section{Let us know how access to this document benefits you.}

\section{Recommended Citation}

Jewell, Curtis J., "The Ripples of Vanport: Navigating Competing Narratives" (2019). University Honors Theses. Paper 725.

https://doi.org/10.15760/honors.743

This Thesis is brought to you for free and open access. It has been accepted for inclusion in University Honors Theses by an authorized administrator of PDXScholar. Please contact us if we can make this document more accessible: pdxscholar@pdx.edu. 
The Ripples of Vanport:

Navigating Competing Narratives

by

Curtis J. Jewell

An undergraduate honors thesis submitted in partial fulfillment of the requirements for the degree of

Bachelor of Arts

in

University Honors

and

English and Communications

Thesis Adviser

Dr. Kathryn Comer

Portland State University

2019 


\begin{abstract}
This thesis analyzes representations of the history of Vanport, Oregon, through the lens of narrative rhetoric. It examines two mainstream texts, one academic and one written for the general public, to establish a foundation for Vanport's dominant representation, before exploring how local nonprofit Vanport Mosaic works to revise that history through community voices. Histories of Vanport have largely focused on its success as a public housing project before the 1948 flood that destroyed the city. In these accounts, the experiences of the residents themselves, including the flood's devastating effects on their community, were overlooked. This neglect inspired the oral history project of Vanport Mosaic, which uses digital media to provide both an alternative historical account of life in Vanport and to disrupt the normative power dynamics of who creates narratives in a way previously impossible. Taken together, these representations demonstrate the subtle erasure of community members' voices in mainstream narratives, as well as the powerful potential of grassroots digital storytelling to complicate those accounts. This case study of Vanport documents contemporary efforts to revise dominant histories and enrich local communities, thereby contributing to future research and advocacy work.
\end{abstract}


"But the fact is that in one's work, one has only two choices- either reproducing existing forms or creating new ones." - Monique Wittig

\section{Introduction}

Narratives inundate our lives; they are an integral part of the human experience. In our increasingly media-saturated environment-rich with racial, economic and social tensions-it's crucial to understand how beliefs and behaviors are influenced by public storytelling. Through repeated exposure, narratives subtly train audiences to understand the world through heuristics. These mental shortcuts serve as useful tools for navigating the worlds we occupy. As these narratives become more heavily used navigational landmarks, they fade into the background of our mental landscape, often overlooked. Considering the power of stories to shape our understanding of others and the world we live in, the strategic use of narratives deserves attention.

Though narratives are often associated with literature, storytelling permeates every aspect of human communication, as researchers and theorists have well established (Fisher; Carr; Gotschall). Narratives help the storyteller understand their own experiences, whether the story is constructed for an audience or internally. As a person constructs and consumes narratives, they are continuously influenced by them and in turn influence others. This occurs on an individual and societal level as "the apparently meaningless stuff of the past is revealed in the present as events that will come significantly together in the future to form a whole plot. The future, in other words, makes the past, just as the past leads to the future" (Puckett 63; emphasis in original). Interpretations of the past 
alter understanding, and thus action, in the present; laws and beliefs are wrapped in the understanding of what came before.

Narrative theory rejects the notion of an unbiased, categorically true narrative construction of history. This thesis, likewise, challenges a singular history by analyzing various narrative constructions of Vanport, Oregon to illustrate how its story has been composed and circulated in public discourse, both historically and in the present. Informed by scholarship on narrative theory and oral history, my thesis explores dominant representations and community (re)representations of Vanport to assess how storytelling choices influence audience interpretation and shape public discourse. I work to show how dominant narratives can valorize the powerful and neglect or erase personal experiences (without malice or intention to deceive), as well as how communities can work to challenge those problematic characterizations. Ultimately, I argue for the value of oral history as a methodological tool for complicating dominant narratives.

Vanport, OR as Case Study

Vanport, OR and the experience of its residents provides a unique opportunity to examine the creation of public discourse around a community in tandem with previously constructed narratives. Vanport was the largest public housing project in the United States at the time it was established in 1942 and the second largest city in Oregon when it was flooded in 1948. At its peak, Vanport was home to roughly 42,000 people and consisted of nearly 10,000 homes. After the flooding, residents were displaced, a large number of them finding refuge in the Albina neighborhood of Portland, Oregon. 
The flooding in 1948 is simultaneously distant and recent. Both creation and demise of the city occurred long enough ago-nearly 71 years to the day of writing this - that historical studies have already been performed multiple times. This provides me with the opportunity to trace the progression of the community's representation through time by looking at each text in turn-marked by a progression from Maben's to Podany's text in this case study. On the other hand, 71 years is a short enough amount of time that contemporary researchers can still observe the impact of some of the actions and institutions established in Vanport into the present day. The story of the Vanport Flood and its survivors is one in which a growing audience is showing interest. Many of the previous residents are still alive today, working to revise and reclaim that history with new narratives.

The story of Vanport has resurfaced in the Portland Metro Area largely due to the work of local nonprofit Vanport Mosaic. Vanport Mosaic is a "memory activism platform" that focuses on providing marginalized communities the ability to share their voices, the recognition of silenced histories and encouraging community participation to combat "collective amnesia." Their work initially focused on collecting and preserving the stories of the Vanport residents but has expanded to marginalized communities more generally. While pursuing my undergraduate degree at Portland State University, I was fortunate enough to work alongside this organization.

$$
* * *
$$

The thesis begins by briefly reviewing some of the literature on narrative theory and oral history as a methodological approach. Through these lenses, I then analyze the dominant representations of Vanport's history in two widely circulated 
texts, before comparing and contrasting those narratives with contemporary treatments of the same history. This reading ofVanport Mosaic's project demonstrates how a local activist group is attempting to revise the public's perception of this community. This thesis evaluates how these narratives are constructed and the complexities inherently present within those constructions. Evaluating representations of a community informs us of the possible understandings generated around the stories we tell. In this way, the work of this thesis can benefit both academic and popular audiences.

\section{Literature Review}

\section{Rhetorical Theories of Narrative}

Narratives exist throughout the world, necessitated by the nature of time and reality (Carr). Narrative studies have defined the concept of narrative as "a theory of symbolic - actions-words and/or deeds - that have sequence and meaning for those who live, create, and interpret them" (Fisher 2). A storyteller must choose what elements to include or exclude. The partial representations create a narrative based on the story's focus. Using Aristotle's treatment of tragedy as the critical first step, Kent Puckett reports on this dichotomy of storytelling known as story and discourse (Puckett 25). This fragmentation is born out of "a conflict over discursive arrangements of the same events" (Puckett 19). Again, every storyteller constructs a unique arrangement.

Story is understood to be the event as it actually occurred. When details are left out of a person's telling, they still exist within the realm of story. Regardless of how a narrative is represented, the events themselves do not change. This stems in 
part from the inability of humans to fully document chronological history and experiences, a point posited by Mink and White, and how part of what is(n't) included is dictated by what it is the creator was able to observe and absorb (Carr). Carr agrees with Mink and White that, because of our limited perceptions, meaning is altered when filtered through a human interpreter (15). This filtration leads to the creation of discourse.

Discourse can be understood as the manner in which a story is composed. Compositional decisions are recognizable when certain aspects are left out of the told story, either to enhance the flow of the plot or to elicit a specific emotional response from the audience. Compositional decisions can be seen as we inform others about our lives. What a writer decides to tell or to leave out indicates how they understand themselves, the implied author, and their imagined audience (Carr; Beard; Herman). That being said, narrative creation may not always be intentional. This emplotment, narrative shape or discourse, is the organizational structure chosen by the narrator(s) to convey meaning (Herman; Phelan \& Rabinowitz).

As discourse changes so does an event's perceived meaning for an audience. As Beard puts it, "the creator or narrator can never be separated from their own values, theories, ideologies, and socio-cultural or historical contexts-from this perspective oral history, like all histories, can be identified as a narrativized historical discourse" (533). Because of this, Jenkins argues there is no categorically true version of history; instead, each recitation is an interpretation from a specific perspective that should be used in tandem with other varied perspectives (Beard). 
The story told is a filtered version of reality that occurs when attempting to understand the past.

It's important to consider the tailoring of a narrative that occurs when it is being communicated. Certain pieces of the story may be left out or emphasized and particular performative strategies may be employed-the use of quickened speech, raised voices, etc.-to increase the likelihood that the audience will be swept away by the narrative and become empathetic (Beard; Gotschall; Mildorf). Because it is possible to intentionally employ these techniques, audience members should consider oral histories critically (Mildorf).

Less explicitly, recent case studies shift the importance of a participant's account from its factuality by looking more intensively at how their participants employ "critical reflection" and how they develop patterns for how they communicate their experiences (Hickson and Drisko). These discoveries reveal information about the participants while they are recounting their experiences (Haynes). Instead of depicting the events as they occurred, the communication of narrative accounts reflects how the informant thinks and interprets the available information.

Postmodernists argue for the contextualization of narratives, and oral histories specifically, because stories acquire meaning within a historical landscape (Beard; Schutz). This historical landscape is dictated by an individual's experiences and society's dominant narratives. When individuals attempt to understand the past, whether consciously or otherwise, events are not approached from a chronological, objective, comprehensive perspective. Instead, the past becomes a pooled resource from which a person can draw to confirm ideas about the present. 
This process mirrors the concept of discourse as a person selectively constructs an internal story and explanation out of the information available to them. As Bruner explains, a person's "life becomes dedicated to the theory or story into which [their] destiny is fitted" (70). In other words, a person's present understanding of the world frames their interpretation of the past. Due to the myriad perspectives and endless differences between them, a narrative construction needs to be contextualized, its perspective elucidated as clearly as possible, to give the reader an opportunity to interact with it critically.

\section{Narrative as Communication}

Though the term narrative has strong associations with fictive creations (novels, plays, movies and the like) it permeates communication of all kinds, in all contexts. The connection to fiction is understandable because, as theorists such as Mink and White posit, narratives are an artificial construct imposed upon events when filtered through the human experience (Carr). Fisher posits that the narrative perspective employs a "dialectical synthesis of two traditional strands in the history of rhetoric: the argumentative, persuasive theme and the literary, aesthetic theme" (2). The ability that narratives have to interact with the audience on both an "argumentative" and "aesthetic" level allows them to target a more varied audience and to increase the likelihood of producing a lasting impact. The narrative paradigm, thus, empowers narrators.

Dominant narratives influence public opinion and memory through the dissemination of particular narratives (Yow; Scheufeleand and Tewksbury). Dominant narratives are created by popular news outlets, public texts, and other widely disseminated media. Frisch created a theory of "composure" to explain how 
the dominant narrative and language influence the public's understanding of specific events throughout history (Beard). In turn, these understandings then influence how individuals remember events as they are filtered through what becomes cultural focal points and the language accessible to these individuals. Some theorists, such as Hayne, see dominant and alternative narratives from a combative perspective, directly fighting with, not adding to one another; however, that belief appears to have shifted with the adoption of a postmodernist perspective(Beard).

\section{Oral History}

The development of oral histories as a research methodology guides a significant portion of this thesis. Oral histories are both a product of a particular type of research, the interviews generated, and a theoretical framework for that research process. Oral history as a methodological tool has multiple applications in "various historical approaches such as social, economic, political, cultural, labour and feminist history" (Beard 530). The varied applications of oral history gathering research projects lead to the need to contextualize alternative histories and to constantly reflect on the co-authorship inherent in the methodology.

A postmodernist approach to history combats the idea of there being a conventional/alternative history. In post-X, a term employed by Beard, history, either all histories or no histories are dominant as our understanding of the past is an intersectional one (Beard). I will be using a postmodernist, intersectional approach to understand texts addressed within this thesis. In doing so, I acknowledge the multiplicity present within the identities of the participants and artifacts mentioned. I do so by focusing on the complex ways in which the 
narratives around the lives of those in Vanport are constructed instead of employing a single lens in my analysis.

Oral history gathering is an active creation on two simultaneous levels (Beard). First, the informant shares a specific story that they believe is pertinent to the research. Second, the researcher reconstructs that story while reporting the information gathered in these testimonies. In my own work, I construct a third narrative, which steps further back from the original narrative of the interviewees and creates yet another story from the ones provided by participants and researchers before me.

Originally, oral history needed to make a stand close to empirical forms of data collection, referencing the information gained from participants as factual data (Beard). This was largely due to the need to establish the methodology as a legitimate form of research. Within an academic paradigm that, predominantly, now recognizes the value of conducting oral histories, it is less important to continuously refer to the oral histories in this way (Haynes 225). The shift into more widely accepted legitimacy has allowed researchers to approach the data they collect with open skepticism. This transition is seen in considerations of trauma narratives and the need to maintain a level of emotional distance and to not read testimonies as having a one-to-one relationship with truth.

Oral histories require more care when revolving around highly traumatic and politicized fields of study (Jessee). A researcher's ability to take notes or create follow up questions deteriorates as they listen to more gruesome stories and are consumed by the informant's narrative (Jessee). Oral historians continuously 
exposed to critical rhetoric confronting dominant narratives may have their own perspectives influenced as they fall victim to focalization (Jessee; Herman).

The possibility for researchers to be unexpectedly influenced by the narratives they encounter does not, however, discredit the methodology as a whole. Oral history allows researchers to collect data unattainable via alternative methods. The decrease in the rate of speech can indicate a person is having difficulty talking or remembering, their wish to emphasize the importance of an event, the trauma they are still recovering from and more. The tone and minutiae of nonverbal communication conveys meaning that cannot be recreated in a textual artifact (Beard; Hickson and Drisko).

The ability to take statements out of context is why Baum argues against editing of the verbatim accounts because of the potential to misrepresent the participants, vandalizing their recitation (Jones). Jones posits that editing is necessary to render certain accounts intelligible to laypeople inexperienced with interpreting verbatim accounts. Editing should be performed to the extent necessary for the prospective audience. If researchers are publishing for a general audience, it would behoove them to edit the testimonies without sacrificing the essence of the interview. Transcription verbatim is counterproductive if it disengages the audience and effectively silences testimonies. Of course, if the prospective study analyzes diction this revision would be inappropriate. Jones also mentions the importance of editing with the participants. accurately represents the story and its meaning. 
The literature review conducted above outlines the foundational concepts of narrative theory employed in this thesis and establishes oral history as a crucial methodological approach for documenting marginalized experiences. Together, these perspectives suggest how oral histories can complicate dominant narratives and therefore merit careful consideration.

\section{Analysis of Dominant Narratives}

To represent the dominant narrative of Vanport, I have selected two texts that most often appear in database and internet searches. I have therefore determined these representations to be the most likely to shape public perspectives. The first text, Vanport by Manly Maben, is an academic history published in 1987. Maben worked closely with the Oregon Historical Society and Multnomah County Library to conduct a deep dive into the history of Vanport. The second text, also titled Vanport, was published by Zita Podany in 2016 . Her text, part of the "Images in America" series, works to inform a popular audience. In short, these texts allow for an analysis that incorporates an older, academic representation of Vanport and a newer, popular perspective of the same history before Vanport Mosaic began their activism work. Among other things, the rhetorical analysis of these texts includes the assessment of elements of diction, story and discourse, visual representation-layout, proximity to other visual elements, order, etc.- and the combination of the general structure and the text's focus to understand the presentation of race, those in power and the community of Vanport as a whole. 


\section{Source 1: Manly Maben's Vanport (1987)}

The first dominant text considered within this thesis is Maben's Vanport. This text approaches the history of Vanport from an academic viewpoint; it originally began as a Master's thesis. The imagined audience is one unfamiliar with Vanport and comfortable navigating longer texts. Maben's imagined audience appears to be educated individuals, academics and historians. Published in 1987, Maben's account of Vanport's history arrives just under 40 years after the devastating flood. This text is being considered as it is the first artifact that attempts to address the history of Vanport in its entirety. The majority of the artifact is comprised of text and is interspersed with images. Although communicating in accessible language the, at times, lengthy prose may deter a casual reader.

Maben works to construct a depiction based predominantly upon information obtained through the Housing Authority of Portland's (HAP's) records; newspapers were "only consulted when necessary [...] except where these records did not exist, such as the planning and building of Vanport [...]” (XIII). Maben notes the superficial nature of national publications and that a few interviews and personal correspondences were used (XIV). Maben thus positions the reader to interpret the text as one primarily informed by those in positions of power and authority while still including the people directly involved in the events.

Within the first sentence of the text proper, Maben begins the rhetorical work of framing his own representation of the history of Vanport within the residents' experience. The rhetorical move of introducing the reader to the history 
of Vanport by referencing the devastation of the flood, including the death count, makes an emotional appeal for the reader to empathize with the residents. Maben's construction further establishes an inclusive narrative by comparing the similarities between Vanport and other cities and housing projects throughout the United States during WWII (XI). By drawing parallels between the community of Vanport and the United States as a whole, Maben welcomes residents into the text while simultaneously normalizing their experience to the reader. This subtly encourages readers to approach the experience of residents empathetically. Valorization of Kaiser

Initially, Maben approaches the narrative around Henry J. Kaiser positively. The text notes the "meteoric" speed of construction while circumventing traditional state funding (1). The text lauds the design and planning as "barren grounds [gave] way to beauty at Vanport" and the "muddy miracle" the city would become $(15,18,13)$. Maben additionally praises Kaiser's intention to accommodate as many residents as possible while using the fewest materials, highlighting Kaiser's focus on financial logistics (8). Kaiser is credited with insisting on establishing Vanport Hospital, "a first class facility", and a fire station dedicated to Vanport (9). Maben does include the HAP's denouncement of Kaiser, citing the inefficient use of funds, but quickly reverts to an appreciative tone when discussing Kaiser's “'super-project”"(10, 11).

Opening the text with such praise creates a positive narrative around Kaiser. The reader is primed to be impressed despite later acknowledgments pointing towards multiple shortcomings, such as not installing back up generators in the hospital and thus performing surgeries by flashlight (40, 41). By lauding Kaiser, 
Maben tells the story of a successful businessman, working to serve his employees while not acknowledging the self-interest that fueled many of the decisions Kaiser made, such as employing women in an industry previously considered "too tough" $(12,16)$. When the reader does encounter suggestions of faulty decision making later on the reader is likely to interpret them as unfortunate accidents and mistakes instead of recognizing the lack of planning and attention. The representation of the HAP is more complex than that of Kaiser.

\section{Villainization and Exoneration of HAP}

Maben begins by portraying the HAP negatively by noting their inability to create the necessary housing within the timeframe needed $(4,5)$. Maben labels the HAP as "badgering" residents and how "regulations seemed endless" under their "dictatorial control"; they retained the right to enter apartments at any time as, within their political paradigm, "immediate self-interest prevailed" (52, 34, 85, 33, 51). Their authority is reported as symbolic, rulings did not carry the weight of municipal law and could not be formally enforced (35). Maben places blame on the HAP for "finally" responding slowly to the repairs needed on infrastructure such as a sewer pipe salvaged by Kaiser from a previously failed project (37). The HAP is depicted as inauthentic, making "the usual syrupy statement[s]" expected of governing bodies (50). In one of the most pointed moments in which the author's evaluation becomes readily available for the audience, the HAP is depicted as unaccommodating and unwelcoming when the "[Vanport Tenant's League] was invited to send one (emphasis by the author) representative" to their meetings, previously held privately, after what Maben claims could "mildly be described as a little 'foot dragging'” (54). 
The ending of Maben's pointed analysis of HAP overseeing Vanport concludes with a list of accomplishments including the "the nursery schools or, more euphemistically, the Child Service Center" - a way to provide 24/7 childcare-and an assessment that "any overall judgment that considers the time and setting must conclude that a superb job was done in running [...] the most difficult housing project in the nation" (68, 55 emphases added). Maben also elevates the HAP's status by mentioning the "astonishing amount of time and detail" put into the city by contrasting it with a dismissive federal government who "apparently" didn't want to provide mail services and the "huffy" response of the FPHA (Federal Public Housing Authority) to requests for funding $(38,40,50)$.

This unexpected turn from looking extensively at HAP's shortcomings complicates the narrative constructed around the HAP. Initially, the reader was guided to consider the HAP with disdain. The HAP is portrayed within the trope of "big brother", an unsuccessful governmental organization abusing power and mismanaging resources (32). By saving the list of accomplishments and significant statement of a "superb job" until the end of his assessment, Maben appears to exonerate the HAP of their mistakes and leaves the reader thinking of the organization through a positive lens (55). The HAP's story becomes a bildungsroman in which the organization struggled and persevered until it found success.

$\underline{\text { Reductive Coverage of Residents }}$

In the beginning, this representation appears focused on the experience of residents and encourages the reader to empathize with them by including personal stories, such as one resident who closed down their business in New York and 
moved to pursue the prosperity promised in the shipyards (2). These residents looked at the new city with gratitude because, the conditions notwithstanding, "at least they were living in homes again" (18). However, despite the reference to a multitude of people coming to Vanport, from throughout the entire country to find work and build new lives, Maben does not include the names of any residents (18). Instead, those referenced by name are officials and public figures such as Johnny Carpenter of KOIN radio (44). Although claiming to focus on life in Vanport, Maben's account appears centered around the officials of Vanport as opposed to the residents. Maben's discourse pays tribute to the idea of residents being the focal point of the narrative while in practice constructs an account centered around officials, governing bodies and public figures.

As the text progresses, Maben's account constructs a narrative that paints the residents of Vanport as ungrateful, disagreeable and distasteful. Maben develops the character arch of Vanport residents by labeling them later as ungrateful as they "finally realized the ride they had been on and hated to see it stop" (66, emphasis added). Those who remained in Vanport are implicitly labeled as incompetent as the "better parents were already looking for someplace else to live" while those who remained "simply turned [their children] loose in the streets" or "walked to enjoy the undesirable atmosphere of Jantzen Beach" $(82,83)$. The inclusion of this intense value judgment is crucial because individual narratives establish their own ethical standards in order to guide their audiences to particular ethical judgments (Phelan and Rabinowitz). Maben subtly labels the survivors and encourages the reader to see the residents as incapable parents and undesirable themselves. 
The issue of Vanport residents' race is depicted as being fraught with difficulty. Maben points to the "troublesome negro worker problem" present after the "importation of blacks" (3). The invoked language blatantly others the African American residents in Vanport. Additionally, the "importation" of "Negroes" draws a parallel between the African American residents and exotic animals $(3,54)$. African Americans make their first appearance as acting agents when Maben states that "[b]lack citizens appeared to be the most active [...]" in community activities and organizations (58). By the time this passing reference is made, the African American experience has already been pushed aside.

Choices of diction, coupled with the inclusion of photographs that feature almost entirely smiling white residents, alienate and dehumanize the African American experience in Vanport (7). Despite "the relatively high proportion of blacks," African Americans are turned into a spectacle (81). The high percentage of African American residents is important to consider in terms of story and discourse. Their relative proportion of the population implies their increased presence within the events and story of Vanport yet Maben diminishes their presence through the discourse presented to the reader.

\section{Critique of Living Conditions}

Next, I turn to look at the living conditions and the lives of residents in Vanport. Maben fires off how buildings featured two washing machines for 56 families; the residents were not allowed to adjust thermostats; the food was more expensive yet lower quality; grocery suppliers took care of their Portland clients before Vanport residents; the solution to an ever-present fear of fires was to "to trust in the lord"; there was an average of 900 and 1,500 calls to complain about 
bed bug and cockroach infestations $(22,25,28,29,30,31)$. The extremely busy, noisy and constantly active quality of the city resulted in "psychic" problems (22). "Administrators and tenants alike agreed that Vanport was not a good place to live" and they "did not particularly enjoy life at Vanport" because it was a "distressing experience" $(25,31)$.

The depiction of the residential life provided by Maben complicates the narrative surrounding Kaiser's role in Vanport. Instead of solely providing information illustrating the successes of construction, Maben incorporates the negative aspects of infrastructure Kaiser created. The incorporation of this information, in such a high amount and directly after the praising of Kaiser, shows how Maben works to provide an all-encompassing perspective on Kaiser; his representation is not limited to solely negative or positive information.

The pictures accompanying the text on pages 26 and 27 tell a different story of Vanport and portray residents smiling and enjoying their well-maintained homes when Maben's text posits that housework was "relatively impossible to do" because of dialectical sleep schedules and that "Vanport's residents did not do much to maintain or improve the looks of the project" (31). The images make it difficult to consider the living condition as anything but peaceful and contradict the meaning Maben's writing attempts to construct $(26,27)$. This contradiction appears to weaken Maben's ethos as the formal construction of the text forces the reader to decide which history to believe, the one presented in the language of the text or in the photographs taken of Vanport.

Inconsistency about Community 
Another contradiction arises in Maben's depiction of community life in Vanport. Throughout the text, Maben makes pointed claims about the "limited community participation" in Vanport (46). He repeatedly depicts the residents as making a "half-hearted attempt" at creating a sense of community in Vanport, glossing over repeated resistance from the FPHA and the HAP (58). Eventually, he states "necessity and conflict", a "school crises" and poorly provided services from the HAP conjured the "first real outpouring of civic spirit" that was "so long absent" $(73,69,71,60)$. Students, not present in photographs like their suited rivals, were "out to wreak vengeance" (72). Maben notes how "community participation had finally arrived" (73, emphasis added). These direct authoritative statements about the lack of community in Vanport establish the reader's understanding but are then contradicted by the content of the text.

Maben provides numerous examples of Vanport residents as being interested in community activities. They joined citizen committees such as the Vanport City Council or Vanport Recreation Association; their plans for adult recreational facilities were repeatedly rejected as "noisy and a nuisance" -considerations for programs and infrastructure were solely for the youth of Vanport; local businesses rallied behind the newspaper owner, paying for more advertising to maintain a locally funded publication; numerous instances of the community revolved around education as well $(44,46,48,82)$.

A student newspaper, later referred to as "amateur" and "juvenile", was formed to heighten community engagement, but the HAP worked against its establishment because it "did not like the paper's independent stance" $(48,47)$. The second newspaper, the Voice of Vanport, was supported by the HAP as it agreed to 
allow censorship and "[r]efrain[ed] from commenting on political or 'other controversial questions" in exchange for cheaper rent, unlike the student organization (48). The story of the newspapers establishes a narrative of Vanport residents wanting to be involved and informed, working to be connected to one another. The HAP is depicted as standing in the way of community. This builds to the negative image of the HAP while working concurrently to diminish the existence of community in the reader's perspective.

These examples and others throughout the text create the story of Vanport residents only being somewhat interested in creating a community and ignores the role of governing bodies in limiting its possibility. Maben identifies the work of students and adults attempting to form community while the HAP is depicted as inhibiting community involvement but skirts responsibility. Maben goes as far as to exonerate the officials by saying "none [of the blame] could be assigned to the board of commissioners" (58). Recalling Frisch's theory of composure, the audience of this text is rhetorically positioned by Maben to view the existence of community, or supposed lack thereof, as stemming entirely from the shortcomings of the residents. The crafted narrative contradicts the information presented alongside it.

\section{Source 2: Zita Podany's Vanport (2016)}

The second dominant text considered within this thesis is Podany's Vanport. This recent text provides a popular perspective on the history of Vanport, relying relies heavily on images to construct the narrative of life in Vanport. Text 
accompanies the images, but the images appear to guide the work and serve as the grounding point for readers. The profuse use of images allows Podany to meet her rhetorical aim of engaging an imagined audience whose interest or academic literacy may be more limited. Additionally, being published in 2016, Podany's representation provides a narrative depiction influenced by the progression of the area's political and social climate while reflecting from a temporal distance.

\section{Valorization of Kaiser}

Podany's historical account spends a considerable amount of time praising Kaiser. She presents a respectable, powerful, suit wearing Kaiser to the reader (12). She writes to highlight how his "innovations revolutionized" and "advanced the shipbuilding industry by leap years"; "he did what he knew best-he took the matter into his own hands" to build a city that was a "dream come true", a "city of firsts", a “"miracle” city (21, 29, 8, 13, 41). Podany continues building Kaiser into a historical hero throughout the text by focusing on the records that were broken, the "many accolades [...] bestowed on the planning" of Vanport, how "[a] lot of thought and planning went into making life comfortable" with "nursery schools, [a] summer session, and [an] extended-day care program", the speed in which it was built, the number of jobs created, the employment of women and extended childcare programs $(41,7,63,29)$.

The focus on the speed of construction and lengthy lists of accomplishments in Podany's representation crafts a narrative around Kaiser of a successful philanthropist. She appears to largely ignore how these achievements came into being out of necessity as opposed to choice and, similarly, ignores the shortcomings of Kaiser's work (20, 19, 20, 54, 30). For example, Podany's account 
briefly addresses the infestations of rats, mice, mosquitoes, and bedbugs that were prevalent due to poor irrigation and planning (35). These issues are mentioned once, a single sentence dedicated to their discussion. In contrast to the narrative constructed by Maben, one that works to elucidate both negative and positive aspects of Kasier, Podany's representation appears single sided. Podany constructs a narrative that depicts Kaiser as a hero and the residents as to him.

Whenever a possibly critical view, such as the connection between poor planning and residential hardship, of Kaiser is presented, Podany quickly backpedals by pulling the reader's attention towards the planning that went into landscaping and how "no expense was spared [...] creating a well-planned, comfortable" and "well protected" home for the residents $(41,14)$. By directly addressing Kaiser's success and glossing over failures, Podany's authorial ethos ultimately diminishes the likelihood of the reader connecting the dike breaking and other infrastructural defects as planning oversights and to instead view them as inescapable or accidental. The congratulatory tone accompanying Kaiser's construction of Vanport is put into sharp contrast with the assessment of the housing project's maintenance.

\section{Villainization of HAP}

Within Podany's account, the HAP embodies inability and childishness. When discussing the need for additional affordable housing, Podany writes, " $A t$ some point, HAP built 4,900 temporary" (29, emphasis added). This dismissive statement introduces the HAP by demeaning their ability to accomplish tasks necessary to the housing project. Podany's discourse later walks back the vague time of "some point" 9 pages later when she provides specific dates $(29,38)$. The 
implied lack of effort of the HAP is shown as impeding progress saying "matters seemed to get even worse" after HAP's involvement (77). The use of seems lacks factual authority and allows Podany to subtly include her own assessment of the organization's participation in Vanport's history. When coupled with previous statements, these rhetorical choices further the hero-making of Kaiser-the supposed philanthropist fighting against oppressive, "miffed" governing powers-discussed in the previous section $(77,32)$.

Although Podany does include partially redeeming assessments of the HAP within her text, her representation creates the image of an inept governmental agency for the reader. Attempts to complicate the HAP's representation are present when Podany describes a picturesque cafeteria in a positive light but is countered with the inclusion of their inability to properly serve the residents (49). Similarly, Podany includes information about the HAP constructing enough units to hold 12,000 people, $30 \%$ of Vanport's peak population, in a few months, to higher building standards than the units constructed by Kaiser, but the author evaluates these efforts for the reader labeling them as "still not enough" $(29,30,59)$. References to the superiority of the housing accommodations made by the HAP and how they taught residents to care for themselves-how to use their appliances and cook nutritional meals-are included significantly later in the text after the initial understanding of the HAP's role in Vanport's history has been established (59). The inclusion of positive information late in the text allows Podany to fabricate a guise of objectivity while still constructing a judgemental evaluation of the HAP's role.

Avoidance of Living Conditions 
The reported living conditions in Vanport contradict the narrative constructed by Podany around Kaiser's success but do not strongly influence the reader's understanding of Vanport's story. Despite praising Kaiser's construction at the beginning of the text Podany later describes the houses as "crackerjack boxes" and "uncomfortable" places prone to electrical fires, where it was "nearly impossible to rest" because of the incessant noise levels $(44,57,55,51)$. Domestic problems, like the fires, are initially framed as being the residents' fault but later Podany briefly alludes to the subpar planning during construction, central heating was inadequate for heating all the apartments, electrical fuses were blown and stoves broken while attempting to use them to heat the units $(70,71,72)$.

Recognition of these infrastructural shortcomings are few and far between, the likelihood that it will be remembered by a casual reader, the imagined audience of the text, is extremely unlikely. The rhetorical move of putting this information later in the text establishes a negative understanding of Vanport residents early on that diminishes the chance of a sympathetic reading. Additionally, by including these negative aspects regarding housing in such minimal amounts the discourse of Podany's representation subtly elevates the successes of Kaiser and diminishes the importance of the residential experience due to its chosen focalization point.

\section{$\underline{\text { Reductive Coverage of Residents }}$}

From the onset of the text, Podany constructs a relationship between the indebted and the debtor. The third word in the introduction reports how the city “owes" its existence to Kaiser (7). The residents and city alike are put into the red, a negative within their own experience. considering the text's limited attention to 
residential life, this immediate framing of indebtedness plays a critical role in the depiction of residents. The residents become a supporting character within the narrative constructed around Kaiser.

Podany's chapter "Life In Vanport" quickly frames the story of childhood in Vanport as circling around crime. This becomes the reader's focal point. The text puts the ownership of the "severe juvenile vandalism problem" upon the residents for not looking after and/or properly reprimanding their children $(70,55)$. It conjures the image of a disconnected city, full of delinquent children. This account does not lead the reader through a critical analysis of what elicited the high crime level, the inability of Kaiser and the HAP to create a dedicated police force or to have school sessions longer than half-days. Access to proper education in Vanport became increasingly difficult throughout its brief history. Podany reports on how the poorly funded school resulted in little in class time and required students to attend split half days ensuring a consistent presence of children on the streets of Vanport $(53,61,64)$.

By not making the connection clear, Podany adds to the story of residents unable to care for themselves. This same result is achieved when Podany provides pages of text exploring the supposed deficiencies of the residents while dedicating a single sentence to the information that contradicts the narrative she crafts. This second dominant narrative glosses over the devotion the students had to their education, obtaining or paying for transportation outside of Vanport when attending high school (61). It also places higher importance on the role of the superintendent who fought to obtain as many buildings for schools as possible (62). 
While important, the focalization of the narrative through those in power takes away from the role played by the residents.

Racial othering is present within Podany's representation. The first photograph of a person of color features an African American man in a quasi-mugshot image used for his union identification card; the man holds a numbered sign in front of him with horizontal lines marking the wall behind (22). This introduction to non-white residents immediately associates the communities of color with the crime discussed in the text. This is enhanced as nearly all of the people pictured are white, featured smiling, wearing suits or going about normal, everyday life while only a handful of images includes people of color $(22,65,67$, $84,91)$. The photo featuring the most people of color is one that was staged to raise money for school activities (91). In one photo, three Native American individuals stand in front of a ship, the image is captioned as "One of Swan Island's most colorful ceremonies" (26).

I bring special attention to the representation of people of color because of how infrequently they are mentioned. With minimal instances of visibility in the text, every occurrence of people of color carries more weight; this is especially true with the included images. The language paired to these images draws attention to the pigmentation of the skin of those pictured and successfully others them. In this way, the communities of color within Podany's story of Vanport are marginalized. People of color are turned into a spectacle as their mere presence becomes something to gawk at.

Critique of Community 
Throughout the text, Podany continuously crafts a narrative about Vanport residents that highlights their lack of community and connection. The text references "reports of tension and discontent among the residents" who were "not very community-minded", "reluctant" and "not eager to volunteer or participate" $(55,80,79)$. Podany adds authority to her assessment by including how the lack "was a surprise to the [HAP]" (60).

After constructing a narrative of an uninterested community, Podany rushes past external factors such as the odd and extended working hours made necessary by the war, how "living conditions were not optimal to really build a sense of community", how the HAP worked to limit the type of community-focused social activities available to adults such as bowling alleys or how parents and other adults came together to offer a variety of after-school activities such as band, hiking, boy scouts and a student run newspaper $(57,79,80,64,83)$. Each of these instances is briefly mentioned and then disappears into the text.

Similar to the pointed claims made by Maben, Podany's direct statement of a lack of community involvement uses her authorial ethos to influence the narrative perceived by the audience. Even as Podany later provides examples of community activities, they are not framed as such. By directly stating there was a lack of community, Podany attaches her authority to this perspective and leads the audience to think along with her narrative construction that is posited in easily digestible terms. Podany's rhetorical decision to mention but not validate moments of community contributes to the narrative developed throughout the text. She perpetuates the idea of residents functioning as footnotes, serving to create Kaiser's while having little value on their own. 
The flooding of Vanport provides an apt example of how the presence of community is avoided within Podany's text. The experience of the residents is pushed further to the margins as the discussion of the flood focuses on everyone except the residents. HAP is demonized by coupling a picture of the flood and a flyer distributed that told residents to stay in their homes (99). Portland Fire and Rescue is depicted as working "valiantly" to save people (104). Podany turns honorable moments into passive occurrences saying "[m]any heroic deeds were performed" (105). Her phrasing echoes the infamous statement 'mistakes were made'. Podany does not attach agency to the residents who have been repeatedly depicted as non-actors within her narrative outside of not believing the sound of sirens and the announcement to evacuate- moments of ignorance and inaction (101).

The role the residents played and their connection to one another is repeatedly ignored. Not attributing heroic acts to the residents, or even suggesting it as a possibility, contributes to the narrative of a city lacking community, unable to connect and care for one another. This depiction is contradicted when Podany posits how so many residents wanted to assist responders that they were considered a hindrance to the emergency crews (110). As within the rest of the text, an understanding is created early on to frame the audience's reading that is later undercut. Despite this later contradiction, much of the text has already been consumed with the initial representation in mind and the brief inclusion allows Podany to feign objectivity without significantly altering the perception of her readers. 
Similar to the rest of the text, Podany shifts between two differing depictions where she 1) creates an image for the reader, the one that dominates the text, and then 2) momentarily walks back the same assertions before returning to bolster the initial one. Although being featured prominently within the body of this thesis, the information surrounding community is given minimal attention and hidden between direct assertions that support the initial narrative construction. This results in creating an artificial duality and complexity while maintaining a clear position.

\section{Analysis of Community Narrative: Vanport Mosaic}

In this study, Vanport Mosaic ${ }^{1}$ provides a non-dominant perspective to the narrative created around the Vanport residents. The local nonprofit has conducted their work since 2015 to recognize, honor and preserve the histories of marginalized communities in the Portland Metro Area. Initially, their work began as an initiative focused on the experiences of Vanport flood survivors specifically. As their perceived ethos within the local area has increased, Vanport Mosaic has shifted its focus to encompass additional communities impacted by racial and ethnic discrimination. In addition to expanding the scope of communities they

\footnotetext{
${ }^{1}$ I find it important to remind the reader of my personal connection to Vanport Mosaic. While attending Portland State University I began working with Vanport Mosaic on two projects. The first was a research project focused on tracing the practice of Redlining in Portland's history, the final product was displayed during a handful of Vanport Mosaic events and published in the Oregon Historical Quarterly Fall 2018 issue. The second project consisted of conducting interviews, none of which are the ones analysed within this thesis, of professors, public officials and city planners in Portland to follow the lines of how housing and gentrification impact the city's communities today. As of the day of publishing, I continue to pursue work with Vanport Mosaic where I predominantly focus on outreach, elevating community engagement and curating exhibits. I had no part in the construction of any of the testimonials used within this thesis.
} 
serve, in 2018 Vanport Mosaic began curating events and conducting outreach throughout the year as well as holding their yearly festival.

I incorporate the analysis of three main sources from Vanport Mosaic into this thesis. The first public artifact I analyze from Vanport Mosaic's work is their website $^{2}$. I then move to look at their social media presence. From here I pivot to the oral history videos accessible on their website and Vimeo, a website made for uploading and archiving video content. This progression is utilized because 1) the official website of Vanport Mosaic provides the most concise, centralized and rhetorically intentional presentation of the organization and their representation of Vanport's history, 2) the social media accounts of Vanport Mosaic are likely to be among the first interactions the public has with the organization and the posts lend insight into their organizational priorities and lastly, 3) the video testimonies provide tangible examples of how the organization represents the experiences of residents for the public and how they complicate the existing narrative around that community.

\section{Mission-Driven Website}

Vanport Mosaic's website immediately works to convince the reader of their dedication. The first image-six children of various ages, races, and ethnicities holding hands-appears to be captioned with their section header, "OUR MISSION” (Vanport Mosaic). This pairing cultivates Vanport Mosaic's ethos as an organization focused on community and "DEDICATED TO CAPTURING, CELEBRATING, AND PRESERVING THE EXPERIENCES” of Vanport residents.

\footnotetext{
${ }^{2}$ This study utilizes an archived version of the Vanport Mosaic website. This digital rendering can be found through The Wayback Machine, a site that archives sites throughout the internet for future reference. The version used for this study was most recently archived on January 3,2019 . The Vanport Mosaic website began a remodel of their website in the beginning of May, 2019. This account does not include this renewed version within its analysis.
} 
Vanport Mosaic labels this history as "essential" and "forgotten". By immediately introducing the reader to this pairing, Vanport Mosaic makes an emotional appeal to the reader in an attempt to convince the audience of their organization's authenticity and the importance of their work simultaneously.

The exigence for their work is attached to Vanport's status as "A FORGOTTEN GITY" (Vanport Mosaic). Vanport Mosaic nudges the reader to question what exactly has been forgotten when there are easily accessible accounts of the city's history. In turn, the validity of those documented histories is called into question. Vanport Mosaic claims their annual festival to be "THE FIRST OF ITS KIND" and to "engage audiences in a deeper understand[ing] of this chapter in Portland's history". They make direct statements in an attempt to convince their audience of the importance that should be associated with their work. Interestingly, the site's next move is to employ the use of statistics-citing the size of the city, how quickly it was constructed and the years in which it existed. Using hard data and factual information appears to buttress the organizations standing as credible.

Establishing themselves as an alternative yet credible source is a high priority for Vanport Mosaic. They directly identify themselves as "a collective of storytellers, media makers, artists, historians, educators, long-term Portland residents, and newcomers" (Vanport Mosaic). This list furthers the organizations standing as an alternative yet informative source for information outside of the dominant ones.

The "About Vanport" section immediately provides contrast to the experience of residents constructed by the dominant narratives. The first sentence 
posits that Vanport was a place that "brought together a mix of races from across the country" into a shared community (Vanport Mosaic). The organization also continues to contribute to its own philanthropic image by noting their desire to "honor the legacy of the Vanport community" (Vanport Mosaic). The critical reader will note the clear weight being placed on the community by Vanport Mosaic and the lack of attention for Kaiser and the HAP. Vanport continues to establish their status as a considerate, community-driven organization by stating their goal to "RECORD, PRESERVE, AND CELEBRATE" the Vanport residents' experience and the importance of developing a "deep knowledge" (Vanport Mosaic). Images on the page include children, shipyard workers and people of color standing together.

The last portion of their website was made up of a "News" section. Here, Vanport Mosaic delineates their community activism through the subsections "Blog" and "Events". The "Blog" consists of posts reflecting on the events held by Vanport Mosaic while "Events" includes, what were, upcoming events. They include calls to action such as "BECOME A SPONSOR FOR THE VANPORT MOSAIC FESTIVAL" and "HELP SUPPORT A 99 YR OLD FORMER VANPORT RESIDENT" that paint the organization as being interested in activating their constituent base (Vanport Mosaic). Posts such as "VANPORT MOSAIC RECEIVES A SPIRIT OF PORTLAND AWARD!" serve as informational posts and as rhetorical moves that add authority and validity to the work being conducted by Vanport Mosaic in the eyes of the reader. Including these headlines in all uppercase draws the attention of the reader and makes sure that these issues, and the clout that is attributed to Vanport Mosaic with them, do not go unnoticed. 
Within the "About Vanport" and "Oral History" sections of their website, Vanport Mosaic includes embedded videos that explain the scope of their work, how it has impacted members of the community and oral histories they have collected and produced over time. These videos will be discussed in more detail below.

\section{Interactive Social Media}

The analysis I conduct of the Vanport Mosaic social media accounts includes posts made from May 1st, 2019 to May 8th of 2019. These dates were chosen due to their proximity to Vanport Mosaic's annual festival, occurring between May 21st, 2019 and June 5th, 2019. I believed that the rhetorical agenda of Vanport Mosaic would be most clear, and the amount of data significantly higher, as the organization attempted to directly motivate their constituents to attend their main project. Additionally, the time span of a week accounted for the possibility of the organization not publishing content on each platform every day. My hope was that by constraining the data in this way it would become manageable while remaining informative. Although Vanport Mosaic does maintain a Twitter page, their account did not make any posts within the timeframe. All of the content posted to Vanport Mosaic's Instagram account is crossposted on their Facebook page verbatim-the text, images, hashtags, and mentions are exact replicas of the content found on Facebook. For the reasons described above, the following section predominantly references their Facebook page. 
During the time frame chosen for analysis, Vanport Mosaic published a total of 26 posts on its Facebook page. Of these 26 posts, 13 of them advertised an event sponsored or held by Vanport Mosaic, 8 shared informative content published by another organization, 4 included spotlights for relevant community members, and 1 posted a video previously produced by Vanport Mosaic.

The amount of time allotted to each type of post informs us of Vanport Mosaic's rhetorical prerogatives. Their Facebook page shows that, first and foremost, the organization is most interested in increasing attendance to their events that focus on educating attendees. Their second most prevalent post includes information from outside sources. These sources include information on, among other things, Cinco de Mayo, the National Day of awareness for Missing and Murdered Indigenous Women and the experience of the Jewish population in Oregon. Vanport Mosaic's use of content generated by other sources allows them to cultivate an ethos of inclusivity by 1 ) interacting with and thus being connected to other organizations and 2) by representing themselves as socially and politically conscious in general as opposed to being solely concerned with their own projects and mission.

The community spotlights are interspersed throughout the nonprofit's posts. They provide information about specific members in the community such as Mariah A. Taylor and Robin Marks on May 4th, a Vanport survivor and the first African American Rose Festival Queen. With these posts, Vanport Mosaic turns the attention of the reader away from the logistical aspects of the organization. Their focus on individuals adds to the idea of history being about the people involved, not only the governing bodies or official organizations, themselves included. 
The last type of post created for their social media presence was also the least common. One post linked back to a video that provided a summary of the work conducted by Vanport Mosaic in the past. Through the use of interviews of artists, students, public and political figures Vanport Mosaic relies on logos and reminds the audience of their previous successes, further bolstering their standing in the present.

\section{Oral Histories and Video Content}

The focus of this study, the narratives constructed around the Vanport residents, helped determine which of the videos and oral histories would be considered for this analysis. Each of the videos produced by Vanport Mosaic would be useful to consider within this thesis, however, it was important to narrow my focus due to the temporal scope of the project. For this reason, I decided to contain my analysis of the videos provided below to public audiences on the Vanport Mosaic website. Two of these videos can be found in the "About Vanport" section of the site while the other 6 are located in the "Oral History" portion. Each video can be found within their catalog on Vimeo.

Vanport Mosaic begins their construction of the narrative around VAnport with VANPORT MOSAIC: HISTORY FROM THE BOTTOM UP. Immediately, the audience reads, and then hears, of how both the city and its history has been forgotten. The video delineates how popular perspectives think of Vanport solely in terms of the flood and don't consider the other implications of the city: a more diverse and progressive population. The video adds to the authority of Vanport 
Mosaic when those interviewed, in this case, a former resident Marge Moss, state that "this project is important because it tells the true story, because the people that lived it are the ones telling the story" (3:45, emphasis added). This rhetorical move allows Vanport Mosaic to further the narrative of an unknown history while augmenting their own authority with that of a resident who experienced the history being discussed. Additionally, this subtly diminishes the standing of previous historical accounts by saying the true story has not been recorded.

The second video shown on Vanport Mosaic's website, Vanport: Oregon's Lost City, was put together by the University of Oregon's Brian Van Peski. Early in this video, the narrator cites the "increasingly racist population" of Portland and how in WWII, that began to change when an estimated 7,000 African Americans moved to Vanport (:30, 1:44). Those interviewed for the video are predominantly African American men who discuss how "Portland was the place to be", in part, because, in Portland "you could get a racial slur, but in the deep south you could get lynched" (2:30, 3:00). Beginning the video with these clips makes race the focalization point through which the history of Vanport is interpreted. It brings the relationship between citizens to the forefront while sidelining statistical informational. This presentation creates a narrative of Black versus White. The discourse present in these representations highlights interpersonal relationships over financial and governmental processes found at the center of the two dominant narratives discussed above.

The story of Vanport is depicted as being hopeful. As the main source of labor, young white men were shipped overseas and that "provided opportunities for minorities, for women, for people of color that had never existed in the 
country before (4:45). This, coupled with images of smiling women and people of color presents the story of Vanport as a positive one, where life in Vanport was "tremendous" despite being segregated (5:05, 5:20). The existence of a community is posited throughout Vanport: Oregon's Lost City as it argues that "during the war that was the most unified era that this country has ever known and will ever know, again" (3:55). The video continues for a total of 15 minutes discussing the history of Vanport through a racial lens. This paints the narrative of Vanport as being nearly entirely about race. The inclusion of this video on their website aids Vanport Mosaic in constructing a narrative of how the experience of Vanport should be largely understood in terms of race.

The video composition of Beatrice Gilmore's testimony creates an air of unexpectedness and surprise around the actual flooding. The audience is thrust into the moment the flood happened (:15). The inclusion of how residents "saw a wall of water behind the car and [they] realized how close [they] were to being washed away" (1:01) makes an emotional appeal to the audience. The audience is consumed by the image of rushing water on the screen and cannot avoid imagining the impending waters. The same appeal is made when Gilmore recounts "knowing that [her] possessions were gone" and Vanport Mosaic follows this statement by nearly 10 seconds of silence and images of the flood waters (1:20). By focusing on Gilmore's traumatic experience of the flooding, Vanport mosaic positions the audience to understand the narrative of Vanport through a lens of tragedy and trauma.

Vanport Mosaic builds upon this trauma narrative by connecting the Vanport flood to Hurricane Katrina. Vanport Mosaic uses a black title screen to 
claim "The Vanport Flood is often compared to Hurricane Katrina" (3:15).

Hurricane Katrina reminded Gilmore of the flood because "she knew how helpless those people felt" (3:28). The audience then watches Gilmore begin to cry for 13 silent seconds before showing clips from Hurricane Katrina's wreckage (3:49). This emotional appeal attempts to connect the more recent feelings of Hurricane Katrina to Vanport. By including this title card, Vanport Mosaic injects their own information into the narrative of the Vanport Flood. They use the ethos of the survivor to prompt the audience to consider the story of Vanport around the destruction that took place with Hurricane Katrina.

\section{Discussion}

When I began conducting research for this thesis, I anticipated finding ways to prove the superiority of oral history. I had been working with Vanport Mosaic for a while and had been a part of some extremely impactful interviews that left me convinced of its value. In fact, I was so thoroughly convinced that the subtitle of my thesis during the prospectus stage was "Subverting Dominant Narratives through Oral History." However, the research I conducted for the literature review and the primary data analysis forced me to reconsider my position. I had fallen victim to the extreme influence oral histories can have over researchers as discussed by Jessee. Narratives, I learned, are not so easily separated into piles of categorically right or wrong, better or worse.

Instead of being clear cut, the narratives I interacted with were multifaceted. They required an intersectional approach in which I had to consider the impact that each rhetorical move may have had upon the overarching narrative. While 
discussing the same series of events, each of the texts considered above elicited significantly different narratives at times while overlapping at others. The dominant narratives marginalized the experiences of the residents to focus on notable figures and those with power while Vanport Mosaic's narrative was constructed to directly combat those representations. What influenced narratives the most appeared to be the perspectives from which the narrators filtered their story. These were both explicit, found in the prefaces or mission statement that contextualized the texts, and implicit, where the authors decided to allocate time for discussion and the diction they employed. Of course, limitations on how information can be represented inherently exists in every discussion. As individuals filter events each "creator or narrator can never be separated from their own values, theories, ideologies, and socio-cultural or historical contexts" and, thus, meaning continuously changes as history is reinterpreted (Beard 533). Narrators are simply unable to experience and document every aspect of time and this gives rise to the differing narratives (Carr).

Each source created an overarching narrative that positioned their audience to interpret the history of Vanport differently. Part of this positioning can be seen with how much time was allotted to each aspect of Vanport's history. Maben constructed a narrative that depicted a more complicated representation of both Kaiser and the HAP. He showed the reader a disconnected Vanport that eventually came together out of necessity. Podany's account lifted Kaiser onto a pedestal due to the importance placed upon the successes of building Vanport. Her representation painted the HAP as incapable. Vanport Mosaic illuminated the often forgotten stories of the people and communities that exist beyond the 
boundary of a texts final page. The representations used tragedy, trauma, and race as their focalization points.

Unlike the dominant texts discussed in this thesis, Vanport Mosaic's narrative construction avoids dealing with both Kaiser and the HAP. This avoidance shifts their audience's attention towards the experiences of the residents. While changing the focus, transitioning to an entirely resident focused narrative means that Vanport Mosaic is unable to directly address the narratives constructed in the dominant representations of the HAP and Kaiser. By not including those in power, Vanport Mosaic alters the overarching, macro-narrative without directly addressing the mezzo and micro-narratives, respectively.

Surprisingly, Vanport Mosaic similarly ignores the living conditions in Vanport. In the videos presented on their website, the portions of the individual testimonies shown to the audience exclude the logistical information of Vanport. Instead, Vanport Mosaic focuses their retelling of the Vanport story to what happened to the individual people. This means focusing on what the residents enjoyed doing and how they connected with the community. The production of these videos echos the rhetoric present on their website where they employ the use of statistics once-in one move they cite the size of the city, how quickly it was constructed and the years in which it existed. Using hard data and factual information buttresses the appearance of the organization's standing as credible while the majority of their representations and rhetorical posturing seems to avoid its inclusion.

One of the main contributions this thesis makes to academic conversations is the juxtaposition of dominant narratives with an organization actively working 
to complicate that same narrative. Instead of looking at multiple narratives that function outside of one another, not responding directly to one another, the analysis of Vanport Mosaic's representation reflects on what a narrative looks like when an author actively works to undermine or counter the work of another.

When an organization conducts oral histories, it is important for them to consider some of the mechanics of the methodology. Researchers and activists alike should keep in mind the power dynamic that exists between them and their interviewees, especially when addressing a marginalized community. In instances such as the title card connect the Vanport Flood and Hurricane Katrina, it's difficult to discern whether the connection was made by the interviewee or by Vanport Mosaic. Ultimately, the researcher is the one putting together the text for publication. Every effort should be made to represent the participants as they intended to present themselves.

The analysis of Vanport Mosaic's representation illustrated how it is possible to elicit a specific response from an audience when attempting to create a particular narrative around a community. Nietzsche's work argued that "behind every officially sanctioned historical point of origin, there is always another hidden or disavowed beginning, another story or stories suppressed in the name of an official social or political interest" (Puckett 94). This can be seen in the agendas of an organization. Although Vanport Mosaic is one that strives to share the voices of the unheard and to strengthen communities, it is still possible that during the process of creating these videos, Vanport Mosaic was pushing their own agenda more than that of the participants. This means that the editing choices may have 
misrepresented the participants while still feeling informative by prompting the survivors to discuss what Vanport Mosaic thought was the heart of their story.

Vanport Mosaic should not, however, be demonized. Oral historians continuously exposed to critical rhetoric confronting dominant narratives may have their own perspectives influenced as they fall victim to focalization (Jessee; Herman). The intense weight of hearing stories that cause the participants themselves to become distraught makes a significant impact on the researcher and activist. This intensity would explain the organizations focus on the flood as it is an extremely emotionally charged event.

Stories with intense plotlines control our focus. Gottschall discusses how the human mind is attracted to stories of drama and horror. Because of this, the use and constant sharing of the stories serve as a critical rhetorical move that is more likely to have a lasting impact on an audience. It is possible that this influenced the manner in which oral histories were produced. As researchers and story gatherers, it is important to be mindful of the power dynamics present between communities and the researcher as participants may fall back on the perceived authority the researcher has, even over their own stories. Additionally, participants may alter accounts, even subconsciously, to coincide with perceived researcher expectations. If Vanport Mosaic was asking pointed questions about the flood and using it as the main topic of discussion, participants would likely have reoriented their story around that event.

Despite the skepticism shared above, oral histories may be most useful when considering communities that are systematically left out of traditional archives, such as newspapers, academic databases and historical texts (Haynes). There has 
been a tendency to still leave the marginalized voices out of the conversation, with many of the oral histories being collected seeming to coincide more so with the genre of biography in which only notable figures in a field are considered (Haynes). This was seen in the work of Maben and Podany that cited the lives of public and political officials in Vanport instead of the everyday person. Jessee pulls from Alessandro Portelli, pointing towards how oral histories are an important tool in the empowerment of "individuals and communities that lack written languages or appropriate spaces in which to comment upon their experiences" (290). The postmodernist perspective acknowledges oral history's ability to diffuse knowledge and authority, give agency to the participant and offer a chance to define their experience in their own terms (Hickson and Drisko).

This study was necessarily bound by the constraints of time and resources, and its analysis would be enriched by further research. For example, newspaper archives, available photos, and similar documents would complement my discussion of dominant narratives. By assessing the resources available to the historians a researcher would be better equipped to analyze the rhetorical moves made. Similarly, analysis of the raw, unedited versions of the oral histories would help elucidate Vanport Mosaic's production choices and the original testimonies. Such choices, in this and other cases, would enable researchers to craft more expansive, nuanced understandings of these narratives.

Importantly, more research needs to be conducted on how communities are impacted after their story has been told. Many accounts stop, as did Maben and Podany, with the end of the event and don't trace how the lives of the communities were impacted afterwords. To truly understand what happens in our world we 
need to follow the repercussions and not choose to stop with the observation of the event itself. This study asks the reader to consider the implications of narratives when formed around a community. In this case, the community traveled from all across the country, giving up financial security, in the hopes of finding fortune and better lives. After the flood, the residents were displaced, losing their homes, belongings, and sources of income. This financially unstable population was then forced to move to wherever they could afford or find a place to live, many of those people moving into the Albina neighborhood in Portland and similar places. Currently, these areas are facing increased levels of gentrification in which the instability of residents, who were already displaced, is pushing them out of their new communities. This pattern of cyclical displacement is not, unfortunately, unique.

As the world witnesses a climate crisis, more communities are being similarly displaced. These climate change refugees must move to wherever is available due to the forces of nature, similar to the residents of Vanport. As this continues to occur, it's important to ask what narratives are being constructed around these communities. Who is receiving attention, praise or blame? How are the communities being represented? Perhaps most importantly, how do these representations influence our understanding of these communities and, thus, the treatment they receive? Such questions are worth considering in the future assessment of those narratives. 


\section{References}

Beard, M. (2017). Re-thinking oral history - a study of narrative performance. Rethinking History, 21(4), 529-548.

Bruner, Jerome. "Self-Making and World-Making." Journal of Aesthetic Education, vol. 25, no. 1, 1991, pp. 67-78. JSTOR, JSTOR, www.jstor.org/stable/3333092.

Carr, D. (1986). Time, narrative, and history (Studies in phenomenology and existential philosophy). Bloomington: Indiana University Press.

Fisher, W. (1984). Narration as a human communication paradigm: The case of public moral argument. Communication Monographs, 51(1), 1-22.

Haynes, K. (2010). Other lives in accounting: Critical reflections on oral history methodology in action. Critical Perspectives on Accounting, 21(3), 221-231.

Herman, D. (2012). Narrative theory : Core concepts and critical debates (Theory and interpretation of narrative series). Columbus: Ohio State University Press.

Hickson, H., \& Drisko, J. (2016). Becoming a critical narrativist: Using critical reflection and narrative inquiry as research methodology. Qualitative Social 
Work, 15(3), 380-391.

Gilchrist, K. (2010). "Newsworthy” Victims? Feminist Media Studies, 10(4), 373-390

Gottschall, J. (2013). The storytelling animal: How stories make us human. Boston: Mariner Books.

Jessee, E. (2011). The Limits of Oral History: Ethics and Methodology Amid Highly Politicized Research Settings. The Oral History Review, 38(2), 287-307.

Jones, R. (2004). Blended Voices : Crafting a Narrative from Oral History Interviews. Oral History Review, 31(1), 23-42.

Mildorf, Jarmila. "Performing Selves and Audience Design.” Narrative Theory, Literature, and New Media: Narrative Minds and Virtual Worlds, edited by Mari Hatavara et al., Routledge, 2016, pp. 256-277.

Phelan, James. Living to Tell about It: a Rhetoric and Ethics of Character Narration. Cornell University Press, 2005.

Phelan, James, and Peter J. Rabinowitz. A Companion to Narrative Theory. Blackwell Pub., 2005.

Puckett, Kent. Narrative Theory: a Critical Introduction. Cambridge University Press, 2016.

Scheufele, D., \& Tewksbury, D. (2007). Framing, Agenda Setting, and Priming: The Evolution of Three Media Effects Models. Journal of Communication, 57(1), $9-20$.

Van Peski, Brian. Vimeo, University of Oregon, 9 June 2019, vimeo.com/851414.

Vanport Mosaic. (n.d.). Retrieved May 05, 2019, from https://www.vanportmosaic.org/ 
---. Vimeo, Vanport Mosaic, 5 June 2019, vimeo.com/150854016.

---. Vimeo, Vanport Mosaic, 5 June 2019, vimeo.com/149108309.

---. Vimeo, Vanport Mosaic, 7 June 2019, vimeo.com/152496755.

Wittig, Monique. "The Trojan Horse.” Feminist Issues, vol. 4, no. 2, 1984, pp. 45-49

Yow, Valerie Raleigh. "Oral History and Memory." Recording Oral History: a Guide for the Humanities and Social Sciences, 3rd ed., Rowman \& Littlefield, 2015, pp. $41-75$. 